\title{
Approach towards the control of rose flower opening by light environment
}

\begin{abstract}
The fact that plants bloom in rhythmic patterns has been widely known since ancient times. ${ }^{1}$ Morning glories (Ipomoea nil), for example, open in a synchronized fashion once a set amount of time passes after dusk (the beginning of the dark period). This means that, although morning glories open at dawn in early summer when it is light late into the evening, they begin opening at night in early autumn when it gets dark earlier in the evening. Meanwhile, rose petals develop only for a set period of time after dawn, after which the bud's development is halted until the next morning. ${ }^{2}$ Our research has shown that this rhythmic growth of rose petals can be observed even in cut flowers, and it is affected by day length and the wavelength of the light. 3 By uncovering the relationship between this rhythmic petal growth and light stimuli, thus deepening our understanding of the mechanisms of petal development, we can pave the way for new technical advances in regulating flower opening through light environmental control. Here we discuss the relationship between rhythmic petal development in cut roses and light stimuli, as well as approaches for controlling lightdependent petal development.
\end{abstract}

Keywords: circadian rhythm, cut rose, flower opening, led, petal growth, photoperiod, post-harvest, Rosa,
Volume 2 Issue 4 - 2018

\section{Takanori Horibe}

Department of Bioscience and Biotechnology, Chubu University, Japan

Correspondence: Takanori Horibe, Department of Bioscience and Biotechnology, Chubu University, Kasugai, Aichi, 487-850I, Japan, Tel +8I-0568-5I-9123, Fax +8I-092-642-2913,

Email t-horibe@isc.chubu.ac.jp

Received: August 05, 2018 | Published: August 09, 2018

\section{Introduction}

The opening of a flower is a phenomenon where sugars and water accumulate in the petals (a sink organ), causing the petal cells to swell dramatically in response. Cell division in the rose petals ends early, during the bud stage, and any later growth is caused by hypertrophy of individual petal cells. ${ }^{4-6}$ Rose petals are also hypothesized to show differences in cellular structure and mechanical strength which lead to different growth rates in adaxial and abaxial epithelial cells, causing the petals to bend outward. ${ }^{7,8}$ In addition, cellular hypertrophy is thought to occur through the accumulation of sugars in vacuoles within the cell, which raises the osmotic pressure inside the cell relative to outside, and through increased distensibility of the cell wall..$^{9-11}$ Together, these changes cause water to flow into the cell. Even in cut flowers, there is a correlation between ease of opening after harvest and the soluble sugar content of the bud: varieties with high sugar content at the bud stage open well after cutting even without sugar supplementation, while those with low sugar content are arrested in a partially open state unless they are given sugar. ${ }^{12,13}$ This example clearly shows that sugars have a large impact on flower opening. Previous research in flower petals has shown that the sugar-metabolizing invertase enzymes are involved in sugar accumulation in vacuoles,${ }^{14}$ while cell wall proteins such as expansins and endotransglycosylase/hydrolase (XTH) are involved in cell wall distensibility. ${ }^{15-18}$ In addition, it was shown that flower opening in tulips is caused by reversible phosphorylation of aquaporins, a family of water-permeable channels. ${ }^{19-21}$ Aquaporins are presumably involved in the flow of water into rose petal cells as well. Thus, hypertrophy of petal cells is thought to require 1) increased osmotic pressure within the cell, 2) relaxation of the cell wall, and 3) the flow of water into the cell (Figure 1). ${ }^{22}$
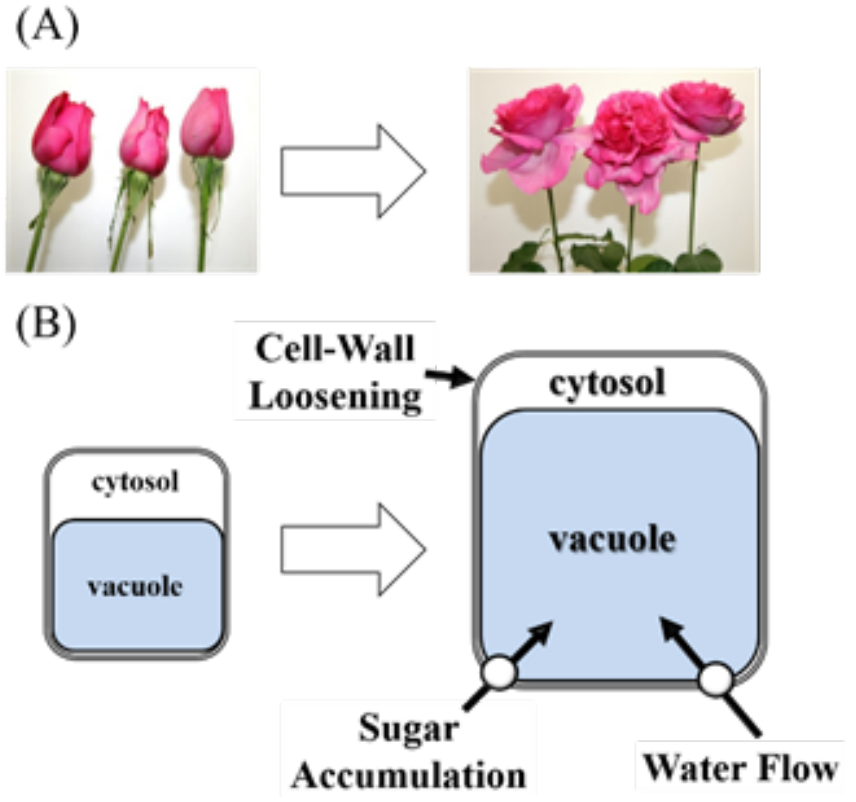

Figure I Flower opening and cell enlargement of rose petal cell. A: Roseflower opening is a process of irreversible petal growth and reflection in which existing cells expand and fresh and dry weights increase; $B$ : Sugar accumulation in vacuole, cell wall loosening, and subsequent water flow into cell are thought to be important for cell enlargement. 


\section{Discussion}

\section{Rhythmic opening of rose flower}

In roses, both flowers on the rosebush and cut flowers have been reported to show a circadian rhythm where flower opening progresses during a period of several hours starting at dawn. ${ }^{23}$ There has been little research into this rhythmic flower opening in roses, and the molecular mechanisms and other details remain unclear. However, the aforementioned XTH, expansins, and aquaporins may also play important roles in rhythmic petal growth in roses. Our previous research has shown that rhythmic petal growth occurs not only in flowers on the rosebush, but also in cut flowers with the leaves removed. ${ }^{2}$ Even single petals removed and placed in water underwent a concentrated period of expansion for several hours starting just before the beginning of the light period. ${ }^{2}$ These results suggest that rose petals sense changes in illumination, and can align their own growth with the day length. In morning glories (Ipomoea nil), red light promotes flower opening, and this effect can be abolished by infrared light following the red light stimulus. ${ }^{24,25}$ In addition, a phytochrome reaction to relatively low levels of light is reportedly involved in sensing the length of the light and dark periods. ${ }^{26} \mathrm{~A}$ similar mechanism may govern photoreception in rose petals; this warrants further investigation. Interestingly, the release of fragrant compounds from roses is also affected by the light environment. For example, the amount of geranyl acetate released follows a circadian rhythm under a consecutive light: dark cycle, but this rhythm is lost under continuous light. ${ }^{27}$ Therefore, we can predict that light stimuli, such as light/dark transitions, affect not only flower opening but also a wide variety of other phenomena in plants.

\section{Controlling rose flower opening by light environment}

Our findings have also demonstrated that different wavelengths of light have different effects on flower opening in cut flowers. ${ }^{3}$ Cut rose flowers (Rosa 'FEbesa'; syn. 'Pretty Woman' in Japan) were retained under a 12 hour photoperiod by white light (fluorescent bulbs), red light (LEDs: peak wavelength $660 \mathrm{~nm}$ ), or blue light (LEDs: peak wavelength $445 \mathrm{~nm}$ ), at a photosynthetic photon flux density of $70-75 \mu \mathrm{mol} \cdot \mathrm{m}^{-2} \cdot \mathrm{s}^{-1}$. They were held in $1 \%(\mathrm{w} / \mathrm{v})$ glucose plus $0.02 \%(w / v)$ 8-hydroxyquinoline monohydrate (Wako Pure Chemical Industries Ltd., Japan) at $25^{\circ} \mathrm{C}, 55 \%$ relative humidity. All treatment groups showed rhythmic flower opening, but the flowers opened more slowly with red or blue light exposure than with white light exposure. The white light source in these experiments used fluorescent bulbs, which produce diverse wavelengths of light. Redsensitive phytochrome photoreceptors have been reported to interact with blue-sensitive phototropin photoreceptors. ${ }^{28}$ This interaction between photoreceptors may explain why white light is more effective at promoting flower opening than single-wavelength red or blue light. As discussed above, it has become clear that the light environment has a large effect on the opening of cut roses, and that rose petals can sense light. Accordingly, if we can uncover more details about the light environment conditions which work to promote or suppress the opening of cut flowers, we may be able to develop new techniques for preserving freshness. Specifically, it would be useful for determining the appropriate light source and day length for suppressing petal growth as much as possible in flowers during distribution and in flower shops, or developing methods for managing cut flower decorations so that the buds open fully as soon as possible. Recently, the market has adopted bucket transport primarily to preserve the freshness of roses, but this method is prone to unwanted petal development during transport. Because of this, the industry must rely on cold chain logistics, along with the associated cost and environmental burden. Being able to control cut flower development via the light environment would solve these problems at the distribution stage.

\section{Conclusion}

It has been shown that light environment control including photoperiod, light strength, and wavelength might become effective tools for controlling cut flower opening and improving its quality. Up to this day, a lot of studies have been conducted for the improvement of vase life and cut flower quality. Thanks to these efforts, several methods including ethylene production/action inhibitors were invented for these purposes. Light environmental control using LED light seems cost-effective and relatively easy to use. Thus, regulation of flower opening by light environment control is important theme to pursue for the further improvement of cut rose quality and vase life (Figure 2).

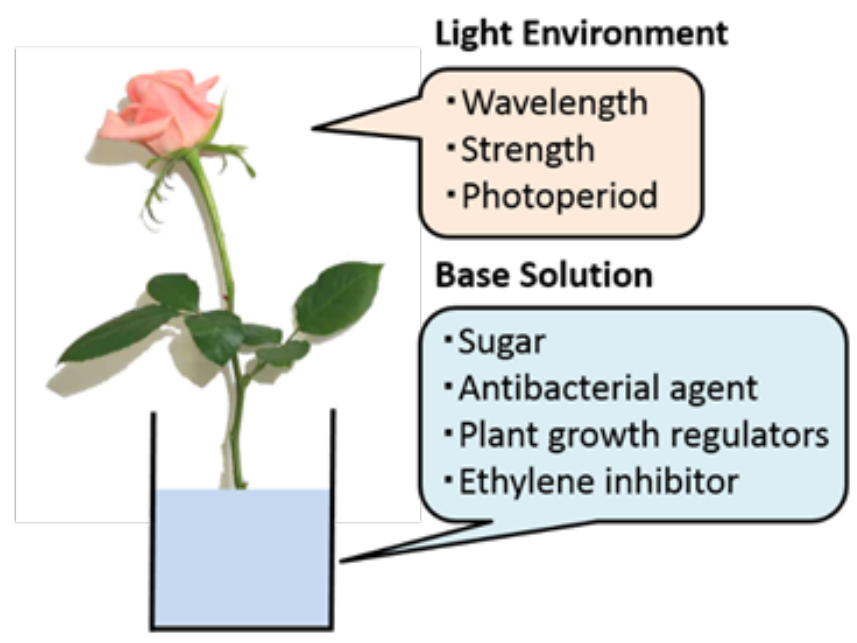

Figure 2 Approach towards the control of rose flower opening by light environment.

\section{Acknowledgements}

None.

\section{Conflict of interest}

Author declares that there is no conflict of interest.

\section{References}

1. Van Doorn WG, Van Meeteren U. Flower opening and closure: a review. J Exp Bot. 2003;54(389):1801-1812.

2. Horibe T, Yamada K. Petals of cut rose flower show diurnal rhythmic growth. J Japan Soc Hort Sci. 2014;83(4):302-307.

3. Horibe T, Yamada K. Diurnal rhythm of petal growth in cut rose flowers. Acta Hort. 2014;1064:241-245.

4. Reid MS, Evans RY. Control of cut flower opening. Acta Hort. 1986;181:45-54. 
5. Evans RY, Reid MS. Changes in carbohydrates and osmotic potential during rhythmic expansion of rose petals. J Amer Soc Hort Sci. 1988;113:884-888.

6. Faragher JD, Mayak S, Tirosh T, et al. Cold storage of rose flowers: Effects of cold storage and water loss on opening and vase life of 'Mercedes' roses. Sci Hort. 1984;24(3-4):369-378.

7. Roberts AV, Debener T, Gudin S. Encyclopedia of rose science. $1^{\text {st }}$ edition Elsevier Academic Press. 2003;2:504-512.

8. Yamada K, Norikoshi R, Suzuki K, et al. Cell division and expansion growth during rose petal development. J Japan Soc Hort Sci. 2009;78(3):356-362.

9. Van Doorn WG, Groenewegen G, Van de Pol PA, et al. Effects of carbohydrate and water status on flower opening of cut 'Madelon' roses. Postharvest Biol Technol. 1991;1(1):47-57.

10. Yamada K, Norikoshi R, Suzuki K, et al. Determination of subcellular concentrations of soluble carbohydrates in rose petals during opening by nonaqueous fractionation method combined with infiltrationcentrifugation method. Planta. 2009;230(6):1115-1127.

11. Ho LC, Nichols R. Translocation of ${ }^{14} \mathrm{C}$-sucrose in relation to changes in carbohydrate content in rose corollas cut at different stages of development. Ann Bot. 1977;41(1):227-242.

12. Ichimura K, Kawabata Y, Kishimoto M, et al. Shortage of soluble carbohydrates is largely responsible for short vase life of cut 'Sonia' rose flowers. J Japan Soc Hort Sci. 2003;72(4):292-298.

13. Ichimura K, Kishimoto M, Norikoshi R, et al. Soluble carbohydrates and variation in vase-life of cut rose cultivars 'Delilah' and 'Sonia'. J Hort Sci Biotechnol. 2005;80(3):280-286.

14. Horibe T, Yamaki S, Yamada K. Effects of auxin and methyl jasmonate on cut rose petal growth through activation of acid invertase. Postharvest Biol Technol. 2013;86:195-200.

15. Cosgrove DJ. Wall structure and wall loosening. A look backwards and forwards. Plant Physiol. 2001;125:131-134.

16. McQueen Mason S J, Cosgrove DJ. Disruption of hydrogen-bonding between plant-cell wall polymers by proteins that induce wall extension. Proc Natl Acad Sci USA. 1994;91(14):6574-6578.
17. Yamada K, Takahashi R, Fujitani C, et al. Cell wall extensibility and effect of cell-wall-loosening proteins during rose flower opening. J Japan Soc Hort Sci. 2009;78(2):242-251.

18. Dai F, Zhang C, Jiang X, et al. RhNAC2 and RhEXPA4 are involved in the regulation of dehydration tolerance during the expansion of rose petals. Plant Physiol. 2012;160(4):2064-82.

19. Azad AK, Sawa Y, Ishikawa T. et al. Phosphorylation of plasma membrane aquaporin regulates temperature-dependent opening of tulip petals. Plant Cell Physiol. 2004;45(5):608-617.

20. Azad AK, Katsuhara M, Sawa Y, et al. Characterization of four plasma membrane aquaporins in tulip petals: a putative homolog is regulated by phosphorylation. Plant Cell Physiol. 2008;49(8):1196-208.

21. Chen W, Yin X, Wang L, et al. Involvement of rose aquaporin RhPIP1; in ethylene-regulated petal expansion through interaction with RhPIP2;1. Plant Mol Biol. 2013;83(3):219-33.

22. Horibe T, Yamada K. Petal growth physiology of cut rose flowers: progress and future prospects. J Hort Research. 2017;25(1):5-18.

23. Evans RY, Reid MS. Control of petal expansion during diurnal opening of roses. Acta Hort. 1986;181:55-63.

24. Kaihara S, Takimoto A. Studies on the light controlling the time of floweropening in Pharbitis nil. Plant Cell Physiol. 1980;21(1):21-26.

25. Kaihara S, Takimoto A. Physical basis of flower opening in Pharbitis nil Plant Cell Physiol. 1981;22(2):307-310.

26. Lumsden PJ. Circadian rhythms and phytochrome. Annu Rev Plant Physiol Plant Mol Biol. 1991;42:351-371.

27. Hendel Rahmanim K, Masci T, Vainstein A, et al. Diurnal regulation of scent emission in rose flowers. Planta. 2007;226(6):1491-1499.

28. Hughes RM, Vrana JD, Song J, et al. Light-dependent, dark-promoted interaction between Arabidopsis cryptochrome 1 and phytochrome B proteins. J Biol Chem. 2012;287(26):22165-22172. 